\title{
Model Blended Learning Dengan Menerapkan Experiential Learning
}

\author{
Diana Ariani ${ }^{\bowtie}$ \\ ${ }^{1}$ Program Studi PGSD, Universitas Islam 45 Bekasi, Bekasi, Indonesia. \\ DOI: https://doi.org/10.21009/JPI.012.02
}

\begin{tabular}{l}
\hline Article History \\
\hline Received : 2018/o8 \\
Accepted : 2018/o8 \\
Published : 2018/o8 \\
\hline Keywords \\
\hline APKL, Blended \\
Learing, Exeperiential \\
Learning
\end{tabular}

\begin{abstract}
This article describes the Blended Learning training model specifically developed by Experience Learning. The model in question is the APKL model, and the model is designed to develop compound learning through the use of experimental learning. APKL itself stands for "analysis, selection, development and implementation." Because this model focuses on blended learning, not an online learning model, Blended Learning will provide a personal learning experience with a variety of learning modes and application-based technology environments.
\end{abstract}




\section{PENDAHULUAN}

Experiential learning didefinisikan sebagai "the process whereby knowledge is created through the transformation of experience. Knowledge results from the combination of grasping and transforming experience" (Kolb, 1984). Experiential learning menekankan pada kapasitas manusia untuk merekonstruksi pengalaman dan kemudian memaknainya (Savin, 2004:31). Dewey percaya bahwa dalam pendidikan adalah proses berkelanjutan untuk merekonstruksi dan menumbuhkan pengalaman, dimana peran pendidik adalah untuk mengelola aktivitas pembelajaran yang dibangun dari pengalaman masa lalu dan menghubungkannya terhadap pengalaman baru. Model experiential learning yang banyak diadopsi dalam bidang pendidikan adalah model experiential learning Kolb. Model experiential learning yang dikembangkan oleh Kolb didasarkan atas penelitian yang dilakukan oleh Lewin, dimana dalam penelitiannya Lewin mengemukakan bahwa proses belajar yang paling baik terjadi apabila difasilitasi oleh konflik antara pengalaman langsung dan nyata peserta didik.

Experiential Learning selama ini sudah banyak dibanyak diterapkan dalam proses pembelajaran di Indonesia, namun penerapannya masih dalam latar pembelajaran tatap muka dan belum dalam setting pembelajaran e-learning. Hal ini disebabkan banyak pihak hanya menjadikan e-learning sebagai fasilitas pendukung experiential learning saja dan bukan menjadikan e-learning sebagai medium utama experiential learning.

Untuk membantu para pendidik menerapkan pembelajaran experiential learning dalam setting e-learning, maka dikembangkanlah model APKL untuk Pengembangan Blended Learning yang menerapkan Experiential Learning.

Mengapa model ini memfokuskan pada blended learning dan tidak pada model online learning, karena dengan Blended Learning dapat memberikan pengalaman belajar secara tatap muka dikombinasikan dengan berbagai modalitas pembelajaran dan konteks aplikasi berbasis teknologi. Blended learning ini memanfaatkan fasilitas elektronik yang ada tanpa menyampingkan nilai-nilai lebih yang ada pada proses tatap muka. Dalam proses ini para peserta didik terpacu untuk belajar secara aktif untuk kemudian segera memperoleh umpan balik tentang kinerja yang telah mereka kerjakan.

\section{Blended Learning}

Blended learning, secara umum dipahami sebagai proses pembelajaran yang mengkombinasikan antara pembelajaran tatap muka dan online. Menurut Thorne (2003), ada dasarnya keberadaan blended learning merupakan suatu respon terhadap keberadaan kemajuan teknologi online dengan praktek terbaik pembelajaran tradisional. Ia menyatakan bahwa blended learning adalah suatu peluang upaya mengintegrasikan kemajuan inovasi dan teknologi yang ditawarkan secara online dengan interaksi dan partisipasi yang ditawarkan dalam pembelajaran tradisional.

Watson (2008) menjelaskan blended learning sebagai konvergensi antara pembelajaran online dengan pembelajaran tatap muka. Secara tegas Ia menyatakan bahwa blended learning adalah pembelajaran yang mengkombinasikan komponen terbaik pembelajaran online dan pembelajaran tatap muka. Hal senada juga diungkapkan oleh Graham (2006) yang mendefinisikan blended learning sebagai kombinasi pembelajaran dari dua model proses belajar-mengajar yang secara historis berbeda, yaitu antara sistem pembelajaran tradisional (tatap muka) dan sistem pembelajaran terdistribusi (distributed learing system). Sistem pembelajaran terdistribusi terjadi karena adanya pemanfaatan potensi yang luar biasa dari teknologi elektronik, khususnya komputer dan internet sehingga memungkinkan siapa saja dapat belajar kapan saja dan dimana saja. Lebih jauh Bonk dan Graham menyatakan bahwa blended learning pada dasarnya mengkombinasikan aspek positif dari dua jenis lingkungan belajar yaitu pembelajaran di kelas dan e-learning (Bonk \& Graham, 2006). Jadi, sama seperti telah diungkapkan sebelumnya bahwa dengan blended learning kelemahan pada pembelajaran tatap muka dapat diatasi dengan kelebihan pembelajaran online. Begitu pula sebaliknya, kelemahan online learning dapat diatasi dengan kelebihan pembelajaran tatap muka. Antara keduanya, pembelajaran tatap muka dan pembelajaran online, pada dasarnya merupakan suatu kesinambungan historis antara cara tradisional dengan cara modern. 
Diana Ariani | Jurnal JPI/Vol.o1/No.02/2018 | H. 08 - 15

Khan (2005), menjelaskan blended learning dari perspektif yang lebih luas. Ia menyatakan bahwa blended learning merupakan kombinasi strategi penyampaian materi yang tepat dalam format yang tepat untuk orang yang tepat pada saat yang tepat. Blended learning mengkombinasikan beragam media penyampaian yang dirancang untuk saling melengkapi satu sama lain dan mendorong terjadinya proses belajar yang optimal. Dengan demikian, dalam mendesain blended learning, ketepatan pemilihan kombinasi media penyampaian baik dalam seting pembelajaran tradisional maupun online menjadi penting. Dimana, fokus utamanya adalah terjadinya belajar secara optimal. Disamping itu, Khan menyatakan bahwa dalam blended learning meliputi kombinasi beragam aktifitas meliputi tatap muka dalam kelas, live e-learning, dan belajar mandiri. Semuanya merupakan kombinasi antara pembelajaran tradisional (dipandu oleh guru/dosen), pembelajaran online sinkronous, belajar mandiri secara asinkronous dan pembelajaran terstruktur yang didasarkan pada pengalaman pemelajar dan mentor (Khan, 2005).

Mengacu pada beberapa definisi di atas, pada dasarnya blended learning memfokuskan pada kombinasi aktifitas pembelajaran sinkronous dan pembelajaran asinkronous. Dalam penelitian ini secara operasional blended learning didefinisikan sebagai suatu bentuk sistem pembelajaran yang mengkombinasikan secara tepat antara aktifitas pembelajaran sinkronous dan aktifitas pembelajaran asinkronous untuk mencapai tujuan pembelajaran yang telah ditentukan.

\section{Experiential Learning}

Pada dasarnya, belajar terjadi ketika "mengalami". Mengalami tidak hanya mengandalkan indera penglihatan dan pendengaran saja tapi semua indera secara simultan. Istilah experiential learning diperkenalkan oleh tokohnya, yaitu David Kolb sejak tahun 1975. Asumsi yang mendasari pentingnya peristiwa mengalami dalam belajar adalah bahwa:

1. Peserta didik, belajar akan lebih baik ketika mereka terlibat secara langsung dalam pengalaman belajar,

2. Adanya perbedaan-perbedaan secara individu dalam hal gaya yang disukai,
3. Ide-ide dan prinsip-prinsip yang dialami dan ditemukan peserta didik lebih efektif dalam pemerolehan bahan ajar,

4. Komitmen peserta didik dalam belajar akan lebih baik ketika mereka mengambil tanggung jawab dalam proses belajar mereka sendiri, dan

5. Belajar pada hakekatnya melalui suatu proses.

Mengacu pada asusmi tersebut, Kolb menciptakan 4 siklus belajar secara berurut walau tidak harus mulai dari urutan pertama, kedua atau seterusnya, sebagai berikut :
1. pengalaman konkrit
(concrete experience/CE);
2. pengamatan reflektif (reflective observation/RO);
3. konseptualisasi abstrak (abstract conceptualization/AC); dan
4. eksperimentasi aktif (active experimentation/AE).

Dalam teorinya, Kolb mengaitkan pengalaman belajar tersebut dengan empat gaya belajar yaitu:

1. gaya belajar divergers; memandang sesuatu dari berbagai perspektif dan mempercayakan sepenuhnya pada curah pendapat dan ide;

2. gaya belajar asimilators; menggunakan reasoning induktif dan memiliki kemampuan untuk menciptakan model teoretis;

3. gaya belajar convergers; percaya sepenuhnya pada reasoning deduktifhipotetik; dan

4. gaya belajar accomodators; melakukan perencanaan dan eksperimen dan mengadaptasikannya terhadap situasi dan kondisi segera atau saat itu. 


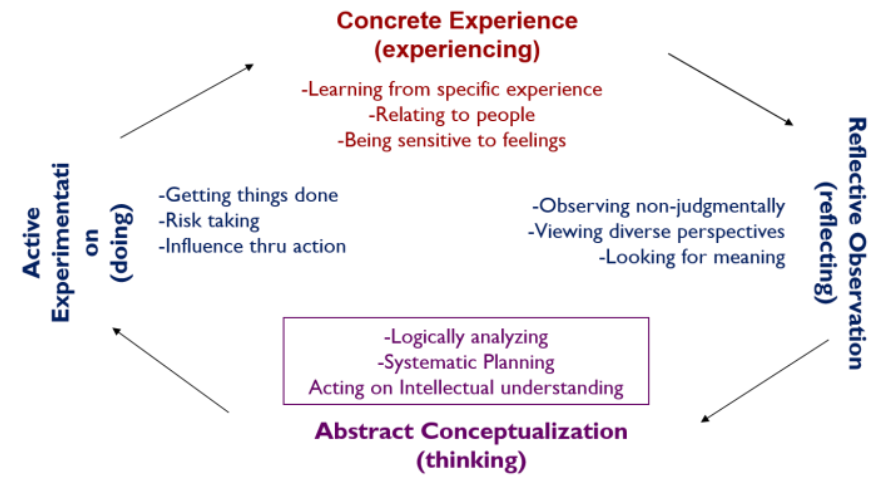

Gambar 1.

Siklus Belajar Kolb

\section{HASIL DAN PEMBAHASAN}

\section{API}

merupakan model yang diperuntukan untuk mengembangkan blended learning dengan menerapkan experiential learning. APKL itu sendiri merupakan akronim dari Analisis, Pilih, kembangkan dan Lakukan. Model ini memfasilitasi pengembangan model blended learning berdasarkan 4 siklus experiential learning menurut Kolb, yaitu : (1) Pengalaman Konkrit; (2) Pengamatan Reflektif; (3) Konseptualisasi Abstrak; (4) Eksperimentasi Aktif. Uraian lebih lanjut mengenai model APKL akan diuraikan sebagai berikut.
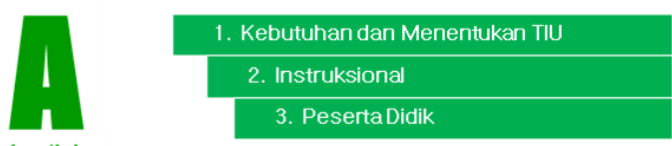

Analisis
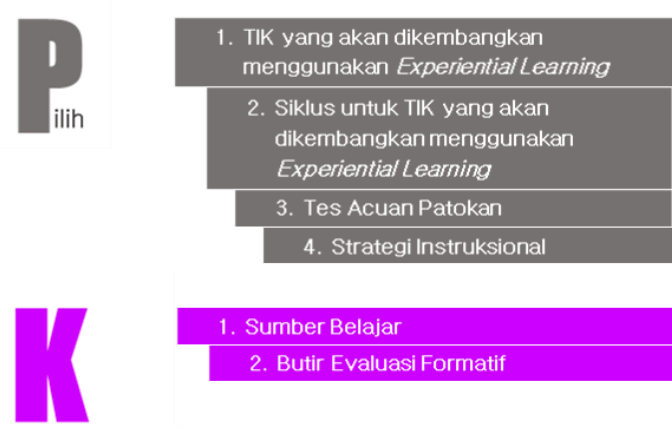

1. Sumber Belajar

2. Butir Evaluasi Formatif

Kembangkan
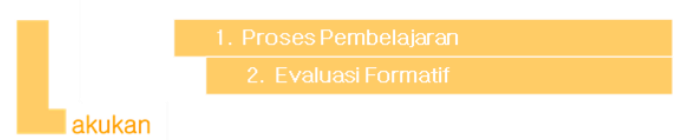

Gambar 2.

Model APKL

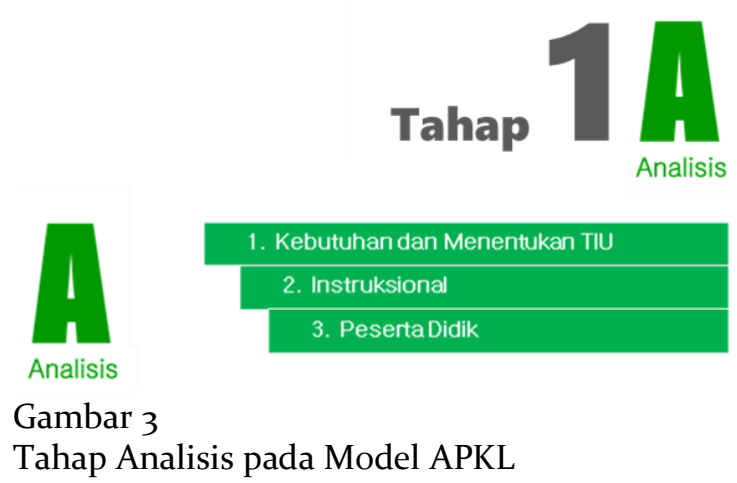

Analisis Kebutuhan dan Menentukan TIU

Analisis kebutuhan harus dilakukan pada awal setiap upaya pengembangan untuk menentukan apakah:

1. Terdapat kesenjangan antara kondisi saat ini dengan kondisi ideal yang seharusnya tercapai.

2. Jika kesenjangan berasal dari Kognitif, Afektif atau Sikap Proses pembelajaran diperlukan untuk mengisi kesenjangan

\section{Analisis Instruksional}

Pada tahap ini, Ahli Materi dan Desainer Pembelajaran bekerja sama untuk melakukan Analisis Instruksional. Selama proses ini, baik dari Ahli Materi dan Desainer Pembelajaran harus mampu melihat konten yang dibutuhkan dari perspektif peserta didik. Analisis Instruksional dapat dilakukan dengan menerapkan metode berikut:

1. Menjabarkan kompetensi umum menjadi kompetensi khusus

2. Menentukan bentuk keterkaitan antar kompetensi yang ada. Bentuk keterkaitan antar kompetesi adalah sebagai berikut:

○ Hierarkis

- Prosedural

- Kluster

- Kombinasi

3. Menyusun peta kompetensi satu mata pelajaran

\section{Analisis Peserta Didik}

Jika sudah dilakukan analisis instruksional, maka selanjutnya adalah menganalisis peserta didik. Menganalisis target peserta didik diperlukan untuk mengidentifikasi berbagai faktor yang akan mempengaruhi desain program. Berikut adalah 
kecenderungan gaya belajar pada siswa menurut Kolb.

a. Gaya belajar divergers;

Berpikir imajinatif, inovatif melibatkan perasaan / intuisi dengan menekankan pengalaman konkret dalam belajar

b. Gaya belajar asimilators;

Belajar dengan mengamati informasi dari berbagai prespektif lalu berefleksi atas informasi tersebut.

c. Gaya belajar convergers;

Belajar melakukan analisis logis dari ide-ide, perencanaan sistematis \& pemahaman intelektual dari situasi yang dihadapi.

d. Gaya belajar accomodators.

Belajar melalui menerapkan teori yang dihasilkan guna memecahkan masalah praktis
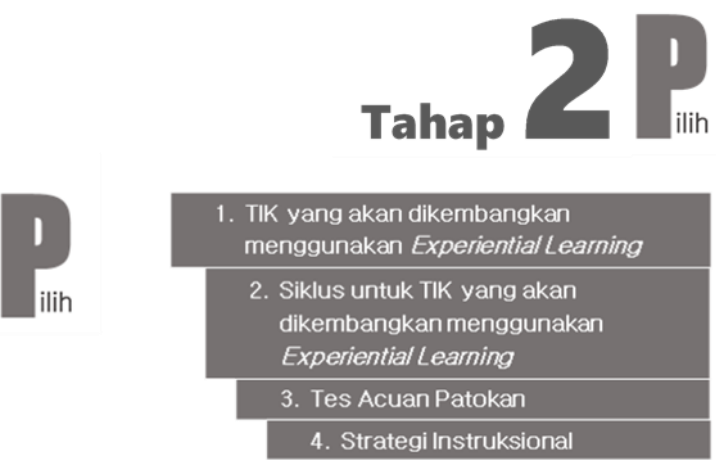

Gambar 4

Tahap Pilih pada Model APKL

\section{Pilih TIK yang akan dikembangkan}

Dengan mempertimbangkan analisis instruksional dan kecenderungan gaya belajar peserta didik, maka selanjutnya adalah menentukan Tujuan Instruksional Khusus (TIK). Dalam model ini, TIK yang telah ditentukan selanjutnya harus dipisahkan antara TIK yang harus dikembangkan dengan Experiential Learning dengan TIK non Experiential Learning.

Metode Experiential Learning hanya akan digunakan untuk mencapai tujuan pembelajaran:

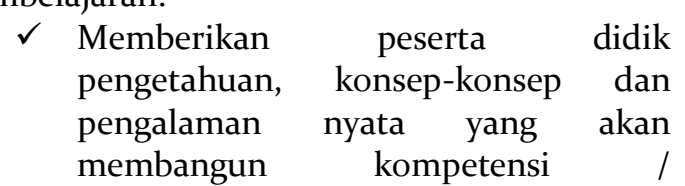

keterampilan melalui penugasanpenugasan nyata.

Seluruh TIK Experiential Learning selanjutnya dikembangkan dalam setting online learning, sedangkan non Experiential Learning akan dikembangkan dalam pembelajaran tatap muka.

\section{Pilih Siklus untuk TIK yang akan dikembangkan}

Tujuan Instruksional Khusus yang memiliki kriteria untuk diterapkan menggunakan Experiential Learning, selanjutnya akan diklasifikasikan sesuai siklus Experiential Learning. Adapun siklus metode Experiential Learning, yaitu:

a. Pengalaman Konkrit Memiliki pengalaman langsung dengan dunia nyata.

b. Pengamatan Reflektif Memahami (refleksi) makna materi pembelajaran dengan melihat fenomena yang terjadi.

c. Konseptualisasi Abstrak Menciptakan konsep baru secara sistematis dari hasil observasi dalam bentuk solusi.

d. Eksperimentasi Aktif Menerapkan solusi yang dihasilkan untuk memecahkan masalah.

\section{Pilih Tes Acuan Patokan}

Menurut Michelle Schwartz, Proses pembelajaran ada banyak cara yang potensial untuk menilai Experiential Learning. Penilaian yang dilakukan membantu peserta didik untuk fokus pada proses belajar sehingga dapat mencapai tujuan pembelajaran.

\section{Pilih Strategi Instruksional}

Tahapan selanjutnya adalah memilih strategi yang sesuai. Strategi Pembelajaran adalah Suatu pendekatan dalam pembelajaran yang sistematis, terorganisir, dan melibatkan semua komponen pembelajaran untuk mencapai kompetensi atau tujuan pembelajaran tertentu secara efektif dan efisien. Kompenen strategi Pembelajaran adalah Urutan Kegiatan, Metode, Media dan waktu.

Pada model ini, pelaksanaan strategi pembelajaran Tatap muka mengikuti dengan penerapan strategi pembelajaran yang sudah familiar digunakan. Adapun untuk strategi 
pembelajaran online dilaksanakan dengan karakteristik dari pembelajaran online.
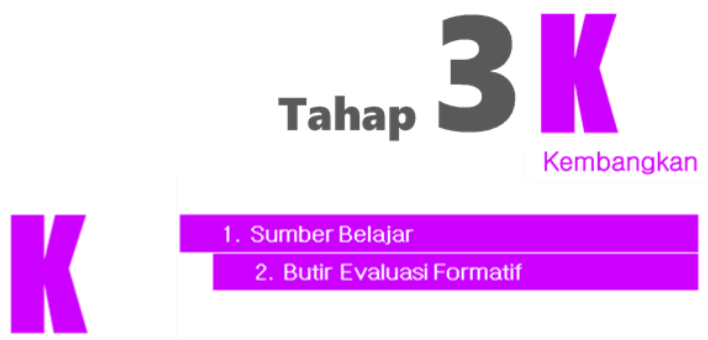

Kembangkan

Gambar 5

Tahap Kembangkan pada Model APKL

\section{Kembangkan Sumber Belajar}

Mengembangkan sumber belajar dilakukan berdasarkan strategi dan tes yang telah disusun. Sumber belajar yang dikembangkan terdiri atas bahan belajar, pedoman bagi pengajar atau fasilitator, tes dan cara penyelenggaraannya, serta pedoman bagi peserta didik. Seperti telah dijelaskan sebelumnya, pada model APKL ini difokuskan pada pengembangan pembelajaran online (belajar mandiri).

Prawiradilaga menyatakan Berdasarkan prinsip essential cognitive processing, seorang peserta didik berhadapan dengan sebuah monitor akan menghandapi informasi yang beragam, seperti informasi tentang navigasi, format dari homepage, bahkan iklan yang tersebar. Untuk itu, peserta didik perlu dibantu dengan penyajian materi yang langsung terkait dengan esensinya. Penyajian esensi materi dimaksudkan untuk menyederhanakan materi yang rumit dan beragam. Dengan demikian, peserta didik tidak memperoleh informasi yang berlebihan (overloaded).

Selanjutnya, Campbell (hal. 150) menyebutkan besaran penggalan atau chunk adalah 100 -150 kata. Rumusan tersebut dikembangkan lagi dengan Guidelines, yaitu setiap penggalan hanya menjawab satu pertanyaan tentang satu bahasan tertentu untuk satu tujuan, dengan besaran antara 1/5 - 1/3 halaman dalam Guidelines.

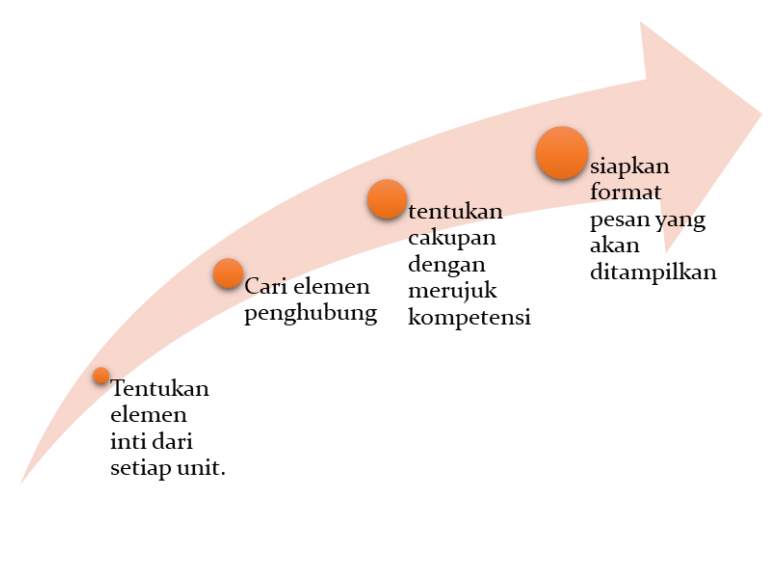

Gambar 6.

Alur pengembangan Sumber Belajar online menurut Prawiradilaga

Untuk memastikan peserta didik melakukan experiential Learning pada pembelajaran Online, selain mengembangkan sumber belajar online juga harus dikembangkan sebuah Lembar Kerja yang berguna membimbing peserta didik untuk melakukan pembelajaran pada waktu askinkronus.

\section{Kembangkan Tes Evaluasi Formatif}

Evaluasi formatif pada model ini bertujuan untuk melihat pencapaian pembelajaran online yang menerapkan experiential Learning, sehingga evaluasi formatif dilakukan dalam format online mengacu materi dari TIK Experiential Learning.

\section{ramp 4}

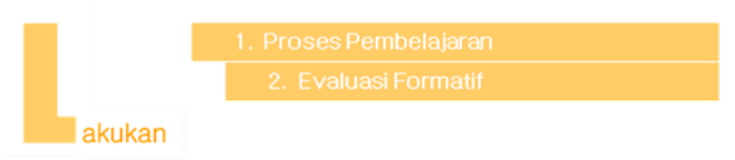

Gambar 7

Tahap Lakukan pada Model APKL 
Lakukan Proses Pembelajaran

Experiential Learning adalah suatu model proses pembelajaran yang mengaktifkan peserta didik untuk membangun pengetahuan dan keterampilan melalui pengalamannya secara langsung. Dalam hal ini, Experiential Learning menggunakan pengalaman sebagai katalisator untuk menolong peserta didik mengembangkan kapasitas dan kemampuannya dalam proses pembelajaran. Berikut tahapan dalam Experiential Learning menurut Nadine Ryan Bannerman.

1. Orientasi : Memberikan arahan yang jelas kepada peserta didik.

2. Klarifikasi: Memaparkan tujuan pembelajaran, jenis kegiatan, agenda kegiatan pembelajaran (jika diperlukan), serta petunjuk untuk bagaimana melakukan aktivitas.

3. Pelaksanaan proses belajar: Melakukan kegiatan pembelajaran yang memberikan pengalaman kepada peserta didik.

4. Refleksi: Proses mempertimbangkan (refleksi) pengalaman belajar yang sudah dilakukan.

5. Generalisasi: Menarik kesimpulan umum mengenai proses yang dilakukan.

6. Aplikasi: Memiliki informasi mengenai bagaimana hasil belajar dapat diaplikasikan di lingkungan nyata.

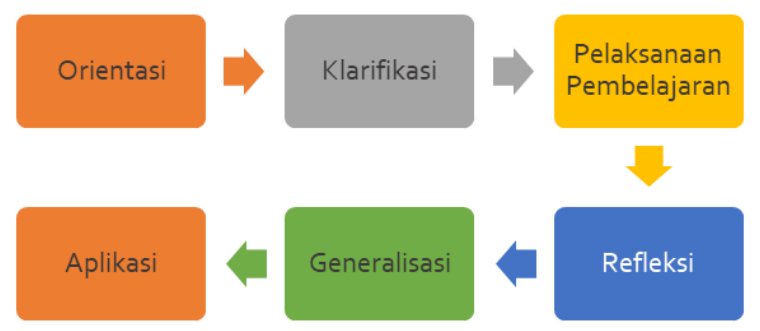

Gambar 8.

Tahapan dalam Experiential Learning menurut Bannerman, 2009

\section{Lakukan Evaluasi Sumatif}

Evaluasi formatif adalah proses menyediakan informasi untuk dijadikan dasar pengambilan keputusan dalam rangka meningkatkan kualitas pembelajaran yang menerapkan Experiential Learning yang dilakukan secara online, sedangkan evaluasi sumatif dilakukan untuk melihat pencapaian Tujuan Instruksional Umum. Evaluasi Sumatif yang dilakukan harus menanyakan keseluruhan TIK (baik Experiential Learning maupun Non Experiential Learning).

\section{SIMPULAN}

Melalui model APKL, beberapa manfaat sebagai berikut dapat dicapai, yaitu menghasilkan suatu sistem pembelajaran blended yang mendasarkan pada suatu model pembelajaran tertentu, dalam hal ini adalah model experiental learning. Selain itu model ini, secara keseluruhan akan menghasilkan suatu prosedur pengembangan pembelajaran blended skala mikro yang juga dapat dijadikan sebagai rujukan bagi para pengembang pembelajaran lain.

\section{UCAPAN TERIMA KASIH}

Terima kasih kepada seluruh pihak di Program Studi PGSD UNISMA 45 Bekasi yang mendukung artikel ini dapat terwujudkan. Semoga E-Learning dapat dikembangkan dengan baik sebagai sebuah sistem di Universitas Islam 45 Bekasi.

\section{DAFTAR PUSTAKA}

Bonk, C., \& Graham, C., (2006). the Handbook of Blended Learning: Global Perspective, Local Design. USA: John Wiley and Sons, Inc.,. San Fransisco, California.

Graham, Charles R.. Blended Learnin System: Definition, Current Trends and Future Direction dalam Bonk, Curtis, J. and Graham, Charles, R., (2006)."The Handbook of Blended Learning: Global Perspective, Local Design". CA, USA: John Wiley and Sons, Inc., San Fransisco.

Healey, M. \& Jenkins, A. (2000) Kolb's Experiential Learning Theory and Its Application in Geographyin Higher Education, Journal of Geography.

Horton, William. (2006). e-Learning by Design. CA: Pfeiffer: John Wiley \& Sons, Inc.. San Fransisco.

Howard, L., Remenyi, Z., \& Pap, G., (2006). "Adaptive Blended Learning Environment". 9th International Conference on Engineering Education, 
Diana Ariani | Jurnal JPI/Vol.o1/No.02/2018 | H. 08 - 15

July 23 - 28, 2006, TN 37235: Vanderblit University, Institute for Software Integrated Systems. Nashville.

Khan, Badrul. (2005). Managing e-Learning Strategies: Design, Delivery, Implementation and Evaluation. Idea Group Inc. USA.

Prawiradilaga, Dewi S., Prinsip Desain Pembelajaran. (2007). Kencana, Prenada Media Group. Jakarta.

Thorne, K. (2003).Blended learning : How to Integrate Online and Traditional Learning. UK and USA: Kogan Page Limited. London. 